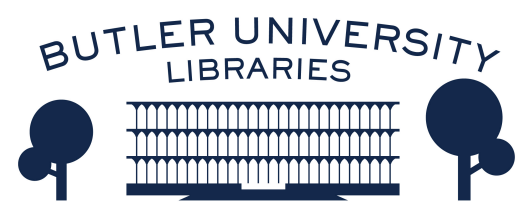

Journal of Hindu-Christian Studies

Volume 25

Article 19

November 2012

\title{
Book Review: "Liturgy of Liberation: A Christian Commentary on Shankara's Upadesasahasri," Reid B. Locklin
}

Anantanand Rambachan

Follow this and additional works at: https://digitalcommons.butler.edu/jhcs

Part of the Religion Commons

\section{Recommended Citation}

Rambachan, Anantanand (2012) "Book Review: "Liturgy of Liberation: A Christian Commentary on Shankara's Upadesasahasri," Reid B. Locklin," Journal of Hindu-Christian Studies: Vol. 25, Article 19. Available at: https://doi.org/10.7825/2164-6279.1525

The Journal of Hindu-Christian Studies is a publication of the Society for Hindu-Christian Studies. The digital version is made available by Digital Commons @ Butler University. For questions about the Journal or the Society, please contact cbauman@butler.edu. For more information about Digital Commons @ Butler University, please contact digitalscholarship@butler.edu. 
Book Review: "Liturgy of Liberation: A Christian Commentary on Shankara's Upadesasahasri," Reid B. Locklin

\section{Cover Page Footnote}

A review of Reid B. Locklin's "Liturgy of Liberation: A Christian Commentary on Shankara's Upadesasahasri" by Anantanand Rambachan. 
North American Protestants: the section on "What is Hinduism?" does not have an equivalent "What is Christianity?" Given this audience, the work possesses a number of strengths. It is written in a very accessible manner, explaining difficult ideas and complicated stories to a lay readership. It gives parallel treatments of Krishna and of Christ, providing a rough balance between them. It makes a strong case to ordinary Christians that they would benefit in their own religious life by sympathetically examining religious traditions and sources other than their own. Finally, it encourages its readers to expand their notions of the divine in ways that could be helpful to them and to the world.

There are two matters which merit further discussion with the author. The first is her total disregard of the importance of the tradition of the baby Jesus and his mother Mary in Roman Catholicism. The Philippines, for example, has an extremely rich Christian tradition of the Santo Niño. Thus the author's statement that "images of the crucified Jesus predominate" in the collections of "most, if not all Christians who have images of Jesus Christ" is certainly open to question. By ignoring the prominence of the baby Jesus and his mother in Roman Catholicism the author not only misrepresents the Christian tradition, but more importantly misses the opportunity for some very interesting comparative work between the Christian and Hindu traditions in relation to divine infants.

The second matter is the way in which the author links the Jesus narrative with ethical behavior, and the Krishna narrative with nonethical "spiritual" activity. For example, Largen argues that the Jesus infancy narratives urge us not to define humanity simply by rationality, excluding children, "or the mentally ill, or those with diminished mental capabilities" (120). The Jesus infancy narratives also provide a "strong, compelling argument against any and all . . . forms of human degradation, exploitation, and commodification, as they demonstrate clearly that Jesus was fully human from birth" (122). The ethical element remains important in Jesus' adult life: he aligns himself "with outsiders: those who are ostracized and cast out; those who are excluded from community" (172). And when Jesus saves people, "he continually shows his persistence at seeking out those whom it would be easy to overlook and forget" (178). On the other hand, the Krishna story is about the spiritual love of God, according to Largen. Thus "the Gita is a profoundly spiritual and even mystical text about the loving nature of God" (155). Moreover, the "ultimate point of Krishna's engagement with the world-both as a child and as an adult-is to lead people into a higher understanding about the world, to convey the knowledge of the right way to live in order to attain peace and happiness, and finally, to invite them to enter into an ultimate loving relationship with Krishna in order to attain union with the Divine" (167). Perhaps Largen does believe that one of the differences in the soteriological implications of the Krishna and Jesus stories is that the former leads to a spiritual enjoyment with the divine, while the latter leads to a divinely inspired ethical engagement with the world. If so, she should say so, and furthermore admit that this line of thinking has a robust history. Overall, however, Largen has done a great service by introducing the divine life through the prisms of Krishna and the non-canonical Jesus, in ways that could be attractive and compelling to a number of ordinary Christians.

Arun W. Jones

Emory University

\section{Liturgy of Liberation: A Christian Commentary on Shankara's Upadesasahasri. Reid B. Locklin. Grand Rapids: Wm.B.Eerdmans Publishing Company, 2011, xviii + 345 pp.}

REID B. Locklin's, Liturgy of Liberation, is a contribution to a series, "Christian
Commentaries on Non-Christian Sacred Texts," edited by Catherine Cornille. Earlier works in 
this series offered commentaries on the Bhagavadgita (ed. Catherine Cornille), the Narada Sutras (Daniel P. Sheridan) and Three Holy Mantras of Srivaisnava Hindus (Francis X. Clooney).

This project of offering Christian commentaries on non-Christian texts, while not unprecedented, certainly breaks new grounds. Reid notes (p.35) the ancient practice in India of teachers of one tradition commenting on the texts and teachings of other traditions. The motive in most cases, however, was apologetic and concerned with demonstrating the untenability of the opposing viewpoint and the validity of one's own. We see this method in the commentaries of Shankara and others in the Vedanta tradition. Here also there is normative tradition in which the commentator is located that certainly informs the nature of the Christian commentator's engagement with the text. Reid acknowledges this and "the sharp limits upon what the Christian hearer can be willing to affirm and to do, but this reader perceives such limits as an expression of weakness, rather than a privileged position from which she can pass judgment (p.321). "There are tensions in this project, but the awareness of one's normative commitment, the willingness to be vulnerable, and the searching humility that opens one to the possibility of deep learning from the sacred text of another tradition distinguish this commentary from the engagement that is entirely apologetic. The motivation and the nature of the reading attempted here break new ground.

Reid's work on the Upadesasahasri extends the commentarial tradition by offering a Christian reading, but this is grounded appropriately in the Advaita lineage of commentaries on this text. There is a heartening recognition of the value and significance of the sampradaya, the traditional flow of wisdom, methods and practices surrounding this text and reaching down to present times. Reid draws often from the commentary of Swami Paramarthananada, a teacher with whom he studied portions of this text. His familiarity with this rich exegetical tradition, and especially with the wider epistemological understanding of scripture as a valid source of knowledge (pramana), that explains so much of the Advaita approach to this text, enrich the authenticity of his commentary and the depth of the dialog that he develops between Advaita and the Christian tradition. Although the Christian dimension of Reid's reading is important for us, I found this commentary to be valuable also as an exposition of the intra-Advaita reception and exposition of the Upadesasahasri. In fact, judged in terms of content volume, this is focus of most of Reid's commentary.

What does the Christian reader of this commentary gain? It is fair to assume that that this is the primary reader addressed. Along with offering her an exposition of the text in its context, Reid intentionally and successfully helps this reader connect with the text by providing reflections that relate the concerns of the text with the Christian tradition. "Advaita Vedanta," as Reid insightfully puts it, " is not a Christian heresy and it stands, at least in its self-understanding, opposed to any and all forms of dualism (dvaita); so perhaps it comes as no great surprise that Shankara's teachings do not quite match those which Iranaeus finds so offensive (p.109)." The divine Spirit in Iranaeus through which "we see and hear and speak," calls to mind Shankara's understanding of the atman as the illumining awareness in every being that makes possible all sense and mental activities. The Advaita insistence that a student must qualify himself (adhikara) to receive scriptural instruction may be related to the Christian practices of "continuous preaching, teaching and ritual," "the cultivation of moral virtue, intellectual assent and an increasingly intense desire for liberation (p.121)." Shankara's critique of prasamkhyana as a practice over and above the revelation of the Upanishads serves as a reminder also to the Christian reader to rely not on transient experiences but "in the God revealed by the scriptures, who perdures and transcends all experiences whatsoever (p.152)." These are only a few examples of Reid's reflections on the teaching of the Upadesasahasri that open the doors to a potentially rich and fruitful dialogue between Christian and Advaitins. If one can ask of anything more here, it is the wish to see some 
of the connections pursued further and their implications elaborated.

Reid's readers, however, are not limited to the community of Christians. This Christian commentary on a Hindu sacred text is likely to be read also by Hindu Advaita theologians (like this reviewer!) who become participants in this conversation between the Christian theologian and reader. What does the Advaitin reader gain? Certainly, a deeper understanding of the Christian theological tradition offered in context of an empathetic study of a Hindu text. For Advaitins, who engage in dialogue with Christians, the learning afforded by Reid's work is invaluable. There is an invitation here also to reconsider important dimensions of the Advaita tradition, often taken for granted, such as the ethic of renunciation, the overcoming of desire, attitudes to physicality, and the status of the other. "There can be no true love and care for others, in other words, where there are no true others to love (p.315)." Reid highlights these issues, cognizant of similar problems in the Christian tradition and the ambiguities associated with the Christian understanding and practice of agape. His critical treatment of Advaita is not one-sided.

Reid's work on the Upadesasahari reflects the rigorous demands of good comparative theology. There is no simplistic conflation of Shankara;s theology with Christianity and Reid recognizes that there are issues, jivanmukti, for example, over with reconciliation may not be possible. He immerses himself deeply and reverentially in text and tradition, suggesting both familiar and novel places for mutual reflection and deep learning. His work demonstrates the possibility of fruitful study of another tradition from a location of commitment to one's own and reverence for the sacred worth of the other.

Anantanand Rambachan

St. Olaf College

\section{Oxford Bibliographies: Hinduism and Christianity. Edited by Chad Bauman,}

\section{Arun Jones, Brian Pennington, Joseph Prabhakar Dayam, and Michelle Voss Roberts, 2012: http://www.oxfordbibliographies.com/ view/document/obo-9780195399318/obo-9780195399318-} 0042.xml?rskey=zjee Zu\&result=2\&q=

THE online, annotated bibliography Hinduism and Christianity is a welcomed, if curiously placed, addition to the Oxford Bibliographies project. Located within the project's subsection on Hinduism and alongside a diverse array of bibliographies that range from Abhinavagupta to yoga and from architecture to politics, Hinduism and Christianity provides a thorough and well-balanced introduction to scholarship on the historical, social, and theological developments of Christianity in India. Although its present content focuses primarily on Christianity in India-the bibliography's content will continue to growit does well to include sections on Hindu responses to Christianity, the impact of Hindu theology and philosophy on theological reflection occurring outside of India, and the Hindu diaspora's encounters with Christianity in the United States and Europe. As the editors note, this field of study is as complicated as it is diverse. Their bibliography is a rich resource that will help both the seasoned scholar and novice inquirer explore more deeply the generals and specifics of Christian and Indian interactions.

Chad Bauman, Arun Jones, Brian Pennington, Joseph Prabhakar Dayam, and Michelle Voss Roberts comprise the project's editorial team. Each brings to the bibliography his or her specialization and expertise, which help to ensure the quality of resources across this wide field. The works these editors have culled together demonstrate the inter- 